\title{
Dual Functional Role of Transmitting Tissue-Specific Glycoproteins from Tobacco for Pollen Tube Growth
}

\section{タバコ花粉管の伸長における媒介組織特異的糖タンパク質の二重の役割}

\author{
Cheung, A. Y., Wang, H., and Wu, H.-m. (1995) Cell 82, 383-393 \\ Wu, H.-m., Wang, H., and Cheung, A. Y. (1995) Cell 82, 395-403
}

Key Words: arabinogalactan protein, deglycosylation, pollen tube growth, tobacco

Higher plant reproduction is known to depend upon highly specific interactions between pollen and pistil, the male gametophyte and the female reproductive organ, respectively. Each pollen grain germinates and extrudes a pollen tube that penetrates the stigma and is elongated through the style to reach the ovary of the pistil to deliver the male gametes for fertilization. Pollen tube growth takes place in the extracellular matrix (ECM) through the stigmatic and stylar transmitting tissues. The pistil ECM is believed to provide physical and chemical supports and directional guidance to the pollen tube growth process, since in vitro pollen tube growth is often slower and lacks a targeted directionality. However, little is known about the components that are involved in the elongation process.

Arabinogalactan proteins (AGPs) constitute a major class of proteins in the transmitting tissue ECM of higher plants. Their abundance in the pistil as well as their stickiness and high sugar content has prompted speculations that these proteins may be involved in pollen tube recognition and that they may serve as nutrients and adhesive substrates for the growing pollen tubes in the transmitting tissues. Previously, the present investigators isolated two closely related cDNAs, TTS- 1 and TTS-2, which encoded proline-rich glycoproteins from tobacco and also showed that they located specifically to the ECM of the transmitting tissues [Wang, H., et al. (1993) Plant Cell 5, 1639]. In the present papers, the authors show that TTS proteins, gene products of TTS genes, belong to the AGP family and demonstrate the possible dual functional role of TTS proteins, gene products of TTS genes, as pollen tubeattracting proteins and as a source of nutrients for pollen tube growth.

Results of these papers can be summarized as follows (for details, please refer to the papers): In the first paper, they purified TTS proteins from tobacco stylar transmitting tissue. The properties of TTS proteins such as abundance of hydroxyproline residues as well as high carbohydrate content, characteristic carbohydrate composition, and reaction with a diagnostic reagent for AGPs allowed them to be categorized as AGPs. TTS proteins showed a tendency to polymerize in a head-to-tail
高等植物の生殖は雄性配偶体である花粉と雌性生殖器官で ある雌莣との特異的な相互作用によって起こることが知られて いる。花粉は発芽すると花粉管を延ばし、花粉管は柱頭を貫通 して花柱を通り、受精が行われる場所である子房に到達する。 花粉管の伸長は柱頭と花柱の媒介組織(transmitting tissue)の細胞 外マトリックス $(\mathrm{ECM})$ で起こる。in vitroで花粉管の伸長を起こ させると伸長が遅く、また伸長の方向性も失うことから、 ECM は花粉管の伸長を助けると共に、伸長の方向を規定していると 考えられている。しかしながら、その伸長に関わる物質的基盤 は殆ど明らかにされていない。

アラビノガラクタンタンパク質(AGP)は高等植物の媒介組 織ECM中の主要なタンパク質群である。雌荵にはAGPが豊富に 存在し、粘着性を持ち栄養源としてょく用いられる糖を多く含 むことから、AGPは媒介組織において花粉管の伸長の際に花粉 管にくっついて誘引する、あるいは伸長の原動力としての栄養 源として機能する、ということが考えられてきた。今回紹介す る論文の著者らは、以前プロリンを多く含む夕ンパク質をコー ドする互いに良く似たCDNA、TTS-1掞よびTTS-2をタバコから 単離し、それが媒介組織のECMに特異的に存在することを明ら かにした [H. Wang ら (1993) Plant Cell 5, 1639]。本論文では、 これらのcDNAがコードするタンパク質であるTTSタンパク質が AGPファミリーの一員であることを示し、花粉管の伸長の際の 栄養源の他、花粉管の伸長方向の誘引タンパク質として恐らく 二重の役割を果たす、という仮説を提唱している。

実験結果の要約は以下の通りである(詳細は本篇を参照され たし)。最初の論文では、タバコの花柱の媒介組織からTTSタン パク質が単離され、その性質が調べられた。TTSタンパク質は ヒドロキシプロリン基と糖の含量が高く、特徵的な糖組成を持 ち、AGP特異的な反応試薬と反応する、といった諸性質から AGPの一員と分類し得ることが分かった。TTSタンパク質は分 子間で方向性を持って重合し易い性質を持つことが分かり、そ 
fashion into oligomeric form in vitro, indicating their role as adhesive substrates to facilitate pollen tube elongation. TTS protein had the activity of promoting pollen tube growth in vitro and also attracted pollen tube in semi-in vivo pollen tube growth cultures. Chemically deglycosylated TTSs lost their bioactivities, and sugar compounds such as monosaccharides or sucrose were found to be less effective in pollen tube growth/ attraction. Further, the pollen tube growth rate was proved to be reduced in transgenic plants in which the level of TTS protein was significantly lowered by antisense suppression or by sense cosuppression. Taken together, TTS proteins were shown to be important both for pollen tube attraction and growth promotion.

In the second article, localization-specific interactions between TTS proteins and pollen tubes as well as localization of the differential glycosylation state of TTS proteins in the stigmatic and stylar transmitting tissues were described. Immunodetection studies indicated that TTS proteins interact with the pollen tube through the means of binding to their surface and tips and also incorporating into their walls. Neither TTS mRNA nor TTS proteins was detected in in vitro grown pollen tubes, suggesting that they were incorporated from the surrounding transmitting tissues by pollen tubes. TTS proteins localized to pollen tube surfaces were released $\mathrm{pH}$-dependently, suggesting that they adhered with pollen tubes through charge interaction. On the other hand, pollen tip-associated TTS proteins were found to bind strongly, indicating another mechanism such as receptor-ligand interaction would be involved in the interaction. Within the transmitting tissue, TTS proteins displayed a gradient of increasing glycosylation from the stigmatic end to the ovarian end of the style, coincident with the direction of pollen tube growth. Deglycosylation activity for TTS proteins was found to be closely associated with pollen tubes. The deglycosylating activity appeared to be specific for TTS proteins, since other transmitting tissue AGPs tested were not deglycosylated under the same assay conditions. The authors speculated that the gradient of increasing glycosylation of TTS protein coincident with the direction of pollen tube growth would come from their deglycosylation as pollen tubes pass through transmitting tissue, and the sugar moieties released would be utilized as nutrients for pollen tube growth.

The papers show clearly the functional importance of TTS proteins in pollen tube growth of tobacco. According to the authors, TTS-related proteins seem to be widely present in solanaceous plants, which leads us to anticipate their universal importance for this cell-migration phenomenon in higher plants.

My particular interest concerning these studies is the deglycosylating activity found in the pollen tube. What is the nature of the "deglycosylation" reaction? The deglycosylating enzyme(s) might also function as a receptor-like molecule for
のくつつき易い性質が花粉管伸長の際に有効に作用する可能性 が示唆された。またin vitroの系で花粉管の伸長を促進する活性 を持つこと、semi-in vivoの花粉管培養の系で花粉管を誘引する ことも確かめられた。TTSタンパク質の糖鎖を化学的に脱離す ることによって上述の生理活性は失われ、また単糖やショ糖の 様な糖も花粉管の伸長促進、誘引には特に効果的ではなかっ た。更にセンス鎖やアンチセンス鎖DNAの導入によってTTS夕 ンパク質の発現量を減少させたトランスジェニックタバコを作 成したところ、花粉管の伸長速度が減少することが分かった。 これらのことからTTSタンパク質は花粉管の誘引拉よび伸長促 進の両方に重要な役割を果たすことが示唆された。

続く論文では、TTSタンパク質と花粉管の部位特異的な相 互作用および様々な糖含量を持つTTSタンパク質の花柱媒介組 織に扔ける局在が調べられた。抗体による染色の結果、TTS夕 ンパク質は花粉管の側表面や先端部分にくっついて存在し、一 部はその花粉管壁内に取り込まれていることが示唆された。 TTSのmRNAおよびTTSタンパク質はin vitroで培養された花粉管 には検出されなかったことから、花粉管壁内に見られたTTS夕 ンパク質は周囲の媒介組織から取り込まれることが確かめられ た。花粉管の側表面に存在するTTSタンパク質は緩衝液のpHを 変えることで花粉管から抽出されることから、電荷によって相 互作用していることが示唆された。一方、花粉管の先端に局在 するTTSタンパク質は緩衝液のpHを変えても抽出されず、花粉 管と強固に結合していることが分かり、その相互作用には受容 体ーリガンド相互作用のような別の機構が介在することが示唆 された。媒介組織中では、柱頭から花柱の子房側にかけて、即 ち花粉管が伸長する方向に従ってTTSタンパク質の糖含量が増 加することが示された。さらにTTSタンパク質から糖鎖を脱離 する活性が花粉管に局在することを支持する結果が得られた。 この糖鎖脱離活性は媒介組織に局在する他のAGPには同じ反応 条件で作用しないことから、TTSタンパク質に特異的なもので ある可能性が示された。この論文の著者らは、花粉管の伸長に 伴ってTTSタンパク質の糖含量が増加する、という現象は花粉 管が媒介組織を通過する際にTTSタンパク質の糖鎖を脱離し、 遊離糖鎖は栄養として機能することに起因すると推測している。

これらの論文では、TTSタンパク質がタバコの花粉管の伸 長に非常に重要な役割を果たしていることが明確に示されてい る。著者らによると、TTSタンパク質はナス科の植物には広く 存在しているようであり、この細胞移動現象にとって同タンパ ク質が高等植物において普遍的に重要な機能を担っていること を予想させる。

ここで紹介した研究に関して私が最も興味を惹かれた点は 花粉管に見い出された糖鎖を脱離する酵素活性についてであ る。この“糖鎖の脱離”とは一体どういった反応機構によるので あろうか?この反応に関与する酵素(群)はTTSタンパク質に特異 
TTS proteins since it appeared to recognize TTS proteins specifically, and therefore could be critical for the strong binding of TTS proteins with pollen tube tip as well as pollen tube guidance. Moreover, the chemical structure of saccharides released by the deglycosylation reaction may be important for efficient function as nutrients. The determination of the reaction mechanism of deglycosylation reaction would thus be of great help in understanding the molecular mechanism of the TTS proteins-driven pollen tube attraction as well as pollen tube growth promotion.

In any case, how this intriguing story develops from now on, is of great interest to us all.

\section{Reported by Suzuki, Tadashi}

Department of Biophysics and Biochemistry, Graduate School of Science, University of Tokyo

Hongo-7, Tokyo 113, Japan
的に働くことから、この分子が花粉管先端におけるTTSタンパ ク質との強い相互作用や花粉管の誘引に関与している可能性も 指摘し得る。また遊離した糖の構造も、それらが効率良く栄養 として利用され得るか否かを大きく左右していることが考えら れる。以上のことから、この酵素活性の本質を見極めることは 花粉管の伸長方向や花粉管伸長の促進を規定する分子機構の解 明の大きな助けになると思われる。

とにもかくにも、この興味深いストーリーの続きを早く知 りたいものである。

東京大学大学院 ·理学系研究科. 生物化学専攻

鈴木匡 